\title{
MANAJEMEN SERTIFIKASI JALUR PORTOFOLIO BAGI GURU SEKOLAH DASAR DI KOTA SEMARANG
}

\author{
Indarti \\ Pendidik di YPI Nasima Semarang \\ Jln. Puspanjolo Selatan No 53 Semarang 50141 \\ indartisuhadisiwi@yahoo.com
}

\begin{abstract}
Abstrak
Penelitian ini bertujuan untuk mengetahui perencanaan, pengorganisasian, pelaksanaan, dan pengawasan sertifikasi jalur portofolio bagi guru Sekolah Dasar di Kota Semarang. Penelitian ini menggunakan pendekatan kualitatif, dilaksanakan di Dinas Pendidikan Kota Semarang. Subjek penelitian terdiri dari Kepala Bidang Pendidik dan Tenaga Kependidikan Dinas Pendidikan, kepala sekolah, dan guru. Teknik pengumpulan data menggunakan metode wawancara, observasi proses pembelajaran, penelusuran dokumen perencanaan pembelajaran dan portofolio. Data yang diperoleh dianalisis dengan analisis kualititatif melalui langkah pengumpulan, penyajian, reduksi, dan penarikan kesimpulan. Hasil penelitian menunjukkan bahwa: (1) Perencanaan sertifikasi jalur portofolio tidak berjalan dengan baik, dari aspek sosialisasi prosedur tidak tuntas dan data tidak valid, (2) Pengorganisasian sertifikasi jalur portofolio tidak berjalan dengan baik, dari aspek penyusunan dan verifikasi dokumen portofolio tidak sesuai dengan buku panduan, (3) Pelaksanaan sertifikasi guru jalur portofolio tidak berjalan dengan baik, (4) Pengawasan sertifikasi jalur portofolio tidak berjalan dengan baik.
\end{abstract}

Kata Kunci: manajemen, sertifikasi guru, profesi 


\title{
THE MANAGEMENT OF THE CERTIFICATION THROUGH THE PORTFOLIO SYSTEM FOR ELEMENTARY SCHOOL TEACHERS IN SEMARANG CITY
}

\author{
Indarti \\ Teacher of YPI Nasima Semarang \\ Jln. Puspanjolo Selatan No 53 Semarang 50141 \\ indartisuhadisiwi@yahoo.com
}

\begin{abstract}
This study aims to investigate the planning, organizing, actuating and controlling functions in the certification through the portfolio system for elementary school teachers in Semarang City. This study employed the qualitative approach, conducted in the Office of Education of Semarang City. The research subjects consisted of the Head of the Educator and Educational Personnel Section in the Office of Education, principals, and teachers. The data collecting techniques included interviews, observations, and document tracing. The data were collected through interviews, supported by observations on learning processes and tracing documents of lesson plans and portfolio. The collected data were analyzed using the qualitative technique involving steps of collection, display, reduction, and conclusion drawing. The results of the study are as follows: (1) the planning of the portfolio system certification does not run well; from the aspect of socialization, procedures are incomeplete and the data are invalid, (2) organization of portfolio system certification does not run well; from the aspects of portfolio preparation and verification, the documents are not in accordance with the guide books, (3) the actuation of the portfolio system certification does not run well, (4) the control of the portfolio system certification does not run well.
\end{abstract}

Keywords: management, teacher certification, profession

216 - Jurnal Penelitian dan Evaluasi Pendidikan Tahun 15, Nomor 2, 2011 


\section{Pendahuluan}

Undang-Undang Nomor 14 Tahun 2005 tentang Guru dan Dosen menyebutkan bahwa guru adalah pendidik profesional dengan tugas utama mendidik, mengajar, membimbing, mengarahkan, melatih, menilai, dan mengevaluasi peserta didik pada jenjang pendidikan tertentu. Undangundang tersebut menjelaskan pula bahwa pengakuan guru sebagai tenaga profesional dibuktikan dengan pemberian sertifikat pendidik. Sertifikat pendidik adalah bukti pengakuan formal yang diberikan kepada guru sebagai tenaga profesional yang telah memenuhi kriteria. Kriteria yang disyaratkan selanjutnya disebut kompetensi guru. Kompetensi guru adalah seperangkat pengetahuan, keterampilan, dan perilaku yang harus dimiliki, dihayati, dan dikuasai oleh guru dalam melaksanakan tugas keprofesionalan. Kompetensi yang dimaksud ada empat, yaitu kompetensi pedagogik, kompetensi kepribadian, kompetensi sosial, dan kompetensi profesional.

Sertifikasi pendidik diselenggarakan oleh perguruan tinggi yang memiliki program pengadaan tenaga kependidikan terakreditasi dan ditetapkan oleh pemerintah. Sertifikasi pendidik dilaksanakan secara objektif, transparan, dan akuntabel. Penyelenggaraan sertifikasi pendidik diatur dengan Peraturan Pemerintah Nomor 10 Tahun 2009 tentang Sertifikasi bagi Guru dalam Jabatan.

Rusman (2008: 440) menyampaikan bahwa sertifikasi guru adalah proses pemberian sertifikat pendidik untuk guru yang telah memenuhi standar kompetensi guru. Sertifikasi guru bertujuan untuk: (1) menentukan kelayakan guru dalam melaksanakan tugas sebagai agen pembelajaran dan mewujudkan tujuan pendidikan nasional, (2) meningkatkan proses dan mutu hasil pendidikan, (3) meningkatkan martabat guru, (4) meningkatkan profesionalisme guru, dan (5) meningkatkan kesejahteraan guru. Pelaksanaan sertifikasi guru merupakan bagian dari pembinaan serta pengembangan profesi dan karir guru. Berdasarkan pernyataan tersebut dapat dijelaskan, bahwa muara utama dari pelaksanaan sertifikasi guru adalah meningkatnya profesionalisme guru dengan penguasaan empat kompetensi guru sebagai upaya peningkatan mutu pendidikan. 
Pelaksanaan sertifikasi guru tahun 2010 telah memasuki usia kelima setelah sertifikasi guru digulirkan mulai tahun 2006. Pelaksanaan sertifikasi guru tahun 2006 hanya berdasarkan Undang-Undang Nomor 14 Tahun 2005 tentang Guru dan Dosen. Pelaksanaannya belum diatur dalam petunjuk pelaksanaan dan petunjuk teknis yang ditentukan oleh Menteri Pendidikan Nasional. Mohammad Imam Farisi (2007: 2) menyatakan bahwa telah terjadi kekosongan peraturan mengenai sertifikasi guru tahun 2006. Akhirnya, pada tanggal 4 Mei 2007 diterbitkan Peraturan Menteri Pendidikan Nasional Nomor 18 Tahun 2007 tentang Sertifikasi bagi Guru dalam Jabatan. Peraturan tersebut mengatur pelaksanaan sertifikasi guru kuota tahun 2007. Dalam peraturan tersebut juga disebutkan ketentuan, bahwa peserta sertifikasi kuota tahun 2006 yang telah mendapatkan sertifikat profesi sebelum Oktober 2007 tunjangannya diberikan mulai 1 Oktober 2007. Selain itu, diterbitkan juga Peraturan Mendiknas Nomor 40 Tahun 2007 tentang Sertifikasi bagi Guru dalam Jabatan melalui Jalur Pendidikan. Kemudian berturut-turut diterbitkan Peraturan Menteri Pendidikan Nasional Nomor 25 Tahun 2008 untuk pelaksanaan tahun 2008, Peraturan Menteri Pendidikan Nasional Nomor 15 Tahun 2009 untuk pelaksanaan tahun 2009, dan Peraturan Menteri Pendidikan Nasional Nomor 10 Tahun 2010 untuk pelaksanaan tahun 2010.

Pelaksanaan sertifikasi guru dari tahun ke tahun menyisakan berbagai persoalan yang berhubungan dengan penentuan kuota, sosialisasi pelaksanaan, penyusunan dokumen portofolio, proses penilaian dokumen portofolio, pengumuman kelulusan, pencairan tunjangan profesi, dan peningkatan profesionalisme guru yang tersertifikasi. Pelaksanaan sertifikasi guru yang diselenggarakan oleh Dinas Pendidikan Kota Semarang pun menyisakan persoalan-persoalan yang menarik. Persoalan-persoalan itu diangkat menjadi masalah penelitian ini. Masalah-masalah yang dapat penulis identifikasi adalah sebagai berikut.

1. Penetapan kuota sertifikasi guru Non-PNS sebesar 15\% per tahun belum terpenuhi karena tidak semua guru swasta tercantum secara akurat dalam database guru. 
2. Sosialisasi penyusunan portofolio yang tidak diikuti oleh seluruh peserta karena kendala geografis sehingga penyusunan portofolio tidak sesuai dengan pedoman.

3. Penyusunan dokumen portofolio tidak sesuai dengan ketentuan karena masih ada beberapa peserta yang menyertakan dokumen baru karena dokumen asli hilang sehingga membuat kembali sesuai dengan tugas yang pernah diembannya.

4. Kesalahan penghitungan nilai akhir dokumen portofolio oleh lembaga penilai merugikan peserta sertifikasi.

5. Pencairan tunjangan profesi tidak dilaksanakan tepat waktu.

6. Sertifikasi guru belum mampu meningkatkan kompetensi guru secara maksimal.

7. Lemahnya perencanaan, pengorganisasian, pelaksanaan, dan pengawasan sertifikasi guru.

Berdasarkan banyaknya permasalahan tentang sertifikasi jalur portofolio bagi guru SD di Kota Semarang maka perlu dilakukan penelitian yang berkaitan dengan manajemen sertifikasi jalur portofolio bagi guru SD di Kota Semarang. Penelitian ini bertujuan untuk mengetahui perencanaan, pengorganisasian, pelaksanaan, dan pengawasan sertifikasi jalur portofolio bagi guru Sekolah Dasar di Kota Semarang.

\section{Metode Penelitian}

Penelitian ini menggunakan pendekatan kualitatif dengan jenis deskriptif yang meneliti tentang manajemen sertifikasi jalur portofolio bagi guru Sekolah Dasar di Kota Semarang. Pendekatan kualitatif dengan jenis deskriptif dilakukan untuk mengumpulkan data secara mendalam mengenai kondisi nyata tentang manajemen sertifikasi jalur portofolio bagi guru Sekolah Dasar di Kota Semarang. Kondisi ini dapat diungkapkan secara alami sesuai fakta-fakta di lapangan.

Tempat penelitian adalah di Dinas Pendidikan Kota Semarang dan beberapa sekolah yang terdiri dari sekolah kategori unggulan, biasa, dan pinggiran yang telah memiliki guru-guru bersertifikat profesi. Waktu pene- 
litian adalah pada bulan Pebruari sampai April 2011 dengan subjek penelitian ini adalah (1) Kepala Bagian Pendidik dan Tenaga Kependidikan Dinas Pendidikan Kota Semarang sebanyak satu orang, (2) Kepala sekolah sebanyak empat orang, dan (3) guru peserta sertifikasi jalur portofolio sebanyak enam orang.

Teknik pengumpulan data yang digunakan adalah wawancara, observasi, dan penelusuran dokumen. Instrumen utama dalam penelitian ini adalah keterlibatan langsung peneliti dalam mengumpulkan data melalui wawancara. deskripsi hasil observasi, dan deskripsi hasil penelusuran dokumen. Bentuk instrumen penelitian yang dibutuhkan untuk mengumpulkan data adalah (a) panduan wawancara, (b) panduan observasi, (c) panduan penelusuran dokumen. Instrumen pengumpulan data dapat disajikan pada tabel di bawah ini.

Tabel 1. Instrumen Pengumpulan Data

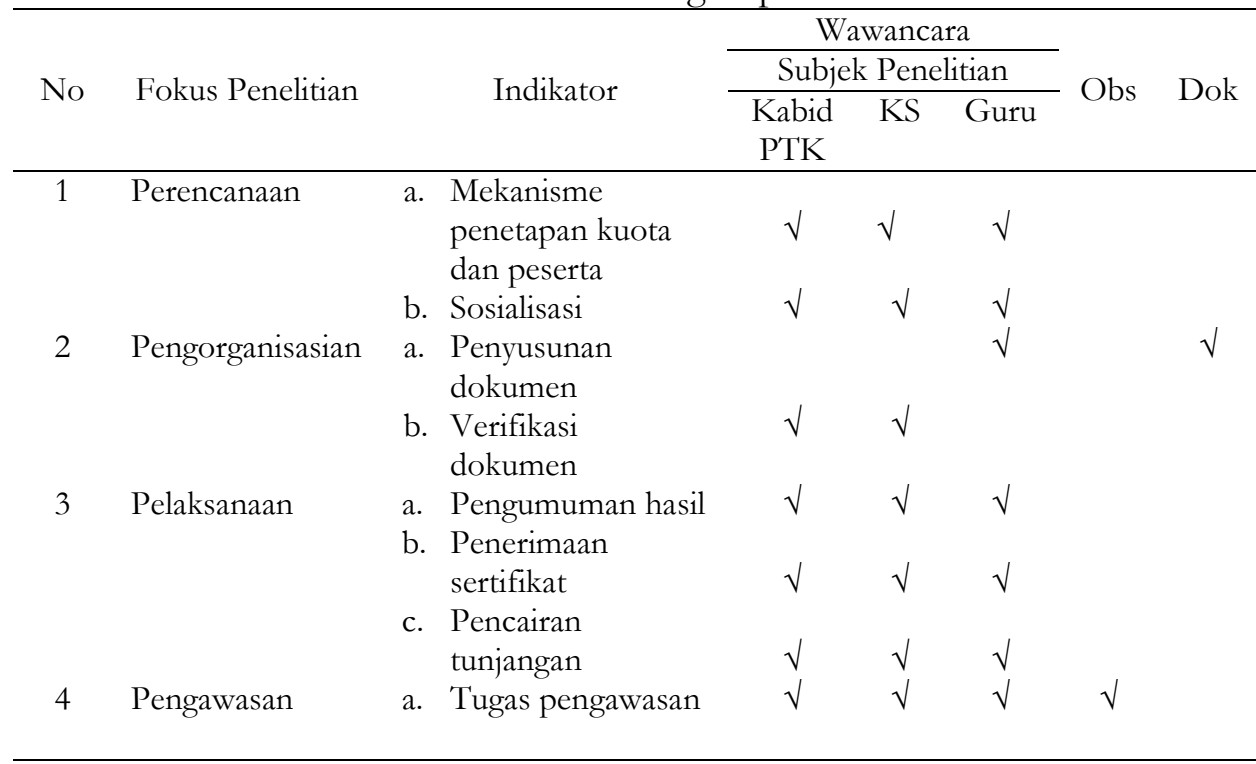

Keabsahan data dilakukan dengan triangulasi sumber dan metode (Moleong, 1998: 86). Triangulasi sumber dilakukan dengan cara memban220 - Jurnal Penelitian dan Evaluasi Pendidikan Tahun 15, Nomor 2, 2011 
dingkan dan mengecek balik derajat kepercayaan informasi yang diperoleh dari subjek satu dengan subjek penelitian lain. Triangulasi metode dilakukan dengan cara mengecek balik derajat kepercayaan suatu informasi yang diperoleh melalui beberapa metode yaitu metode wawancara dengan observasi dan wawancara dengan penelusuran dokumen. Analisis data terdiri dari pengumpulan data, reduksi data, penyajian data, dan verifikasi data atau penarikan kesimpulan (Miles dan Huberman, 1994).

\section{Hasil Penelitian dan Pembahasan}

Penelitian ini memfokuskan pada manajemen sertifikasi jalur portofolio bagi guru SD yang meliputi empat fungsi manajemen yaitu perencanaan, pengorganisasian, pelaksanaan, dan pengawasan.

\section{Perencanaan}

Perencanaan sertifikasi guru jalur portofolio bagi guru Sekolah Dasar meliputi mekanisme penetapan kuota dan penetapan peserta. Penetapan jumlah kuota Dinas Pendidikan Kota Semarang ditentukan oleh Bidang Profesi Pendidik dan Kependidikan Direktorat Jenderal Pendidikan Dasar Kementerian Pendidikan Nasional (Bid. P2TK Dirjen Dikdas Kemendiknas) yang masuk kuota Pendidikan Dasar (Dikdas). Kuota kabupaten/kota dihitung bersama antara LPMP, Dinas Pendidikan Propinsi, dan Dinas Pendidikan Kabupaten/Kota yang terdiri dari kuota guru PNS dan guru Non-PNS yang dihitung secara proporsional mulai dari guru-guru pendidikan dasar. Kuota guru yang berstatus Non-PNS ditetapkan minimal 15\%. Penetapan peserta untuk jenis dan jenjang pendidikan ditentukan oleh Dinas Pendidikan Kota/Kabupaten. Berdasarkan data di Kota Semarang, kuota 15\% untuk guru Non-PNS belum pernah terpenuhi.

Mekanisme penetapan kuota dan penetapan peserta yang dilakukan oleh Dinas Pendidikan Kota Semarang telah sesuai dengan mekanisme yang ditetapkan berdasarkan Buku 1 tentang Pedoman Penetapan Peserta Sertifikasi Guru. Namun, dalam prosesnya terjadi permasalahan dan membutuhkan waktu yang cukup lama. Proses penetapan peserta bermasalah 
pada proses verifikasi yang dilakukan oleh kepada sekolah. Berdasarkan penelitian masih banyak kekeliruan pada data hasil verifikasi kepala sekolah, sehingga rekapitulasi data yang semestinya sudah selesai, harus diolah lagi dari awal. Masih ditemukan ketidakpahaman tentang penghitungan masa kerja, kualifikasi akademik, dan pelaporan keikutsertaan sertifikasi.

Perencanaan lain yang dilakukan dalam setifikasi guru melalui jalur portofolio adalah proses sosialisasi bagi peserta tentang penyusunan portofolio. Pelaksanaan sosialisasi dilaksanakan singkat antara 2-3 hari dan penjelasan yang diberikan pada peserta kurang memadai.

Hasil penelitian terkait perencanaan sertifikasi jalur portofolio menunjukkan bahwa Dinas Pendidikan tidak melakukan perencanaan secara maksimal. Hal ini dapat ditandai dengan lemahnya sistem database guru yang dimiliki oleh Dinas Pendidikan. Ketidakpahaman dan ketidaktelitian kepala sekolah dalam melakukan verifikasi menambah permasalahan yang ada.

Proses sosialisasi bagi peserta tentang penyusunan portofolio dan informasi lain tentang sertifikasi pun tidak dilaksanakan secara maksimal sehingga peserta mengalami kesulitan dalam penyusunan dokumen portofolio. Seharusnya prosedur sosialisasi tetap dilaksanakan setelah proses penentuan kuota dan peserta. Sosialisasi dilakukan lewat penjelasan umum dalam suatu forum yang mengundang guru-guru yang masuk daftar tetap peserta sertifikasi jalur portofolio. Sosialisasi lisan itu harus dilengkapi dengan pembagian buku pedoman penyusunan dan alur portofolio atau fotocopynya kepada semua peserta. Setelah itu, kepala sekolah wajib memperjelas isi sosialisasi tersebut dalam rapat internal sekolah.

\section{Pengorganisasian}

Pengorganisasian sertifikasi jalur portofolio dilakukan pada aspek penyusunan dan verifikasi dokumen portofolio. Dokumen portofolio merupakan bukti fisik untuk menggambarkan pengalaman berkarya atau berprestasi dalam empat kompetensi yang dicapai selama menjalankan tugas profesi sebagai guru dalam interval waktu tertentu.

Kompetensi pedagogik dinilai antara lain melalui dokumen kualifikasi akademik, pendidikan dan pelatihan, pengalaman mengajar, serta peren222 - Jurnal Penelitian dan Evaluasi Pendidikan Tahun 15, Nomor 2, 2011 
canaan dan pelaksanaan pembelajaran. Kompetensi kepribadian dan kompetensi sosial dinilai antara lain melalui dokumen keikutsertaan dalam organisasi dan aktivitas sosial kemasyarakatan serta penilaian dari atasan dan pengawas. Kompetensi profesional dinilai antara lain melalui dokumen kualifikasi akademik, pendidikan dan pelatihan, pengalaman mengajar, perencanaan dan pelaksanaan pembelajaran, prestasi akademik, dan karya pengembangan profesi.

Waktu penyusunan dokumen yang relatif singkat, yaitu antara 2-3 hari membuat kebingungan tersendiri bagi peserta mengingat banyaknya komponen portofolio yang harus dipenuhi. Hasil penelitian menunjukkan bahwa bagi peserta yang memiliki dokumen pribadi yang lengkap dan memadai, maka dia tidak mengalami kesulitan dalam menyusun dokumen portofolio. Rata-rata mereka membutuhkan waktu hanya 2-3 hari dengan hasil penyusunan yang sangat baik, dibuktikan dengan skor yang diraih mencapai 1.000 lebih.

Kebalikannya, bagi peserta yang tidak memahami pedoman penyusunan, tidak memiliki dokumen yang memadai atau peserta yang mempunyai dokumen tetapi tidak tertib mengarsipkan, maka mereka mengalami kesulitan dalam penyusunan dokumen. Temuan ini diperkuat dengan banyaknya peserta sertifikasi yang tidak menyusun sendiri portofolionya dan memanfaatkan biro jasa penyusunan dokumen dan mengeluarkan biaya rata-rata $\mathrm{Rp} 400.000,00$. Beberapa dokumen yang memungkinkan bisa dilakukan biro jasa tersebut antara lain mengetikkan silabus dan RPP, membuatkan PTK, membuatkan biodata, cover, dan format isian setiap komponen. Ada juga yang sampai mampu menambahi piagam atau sertifikat kegiatan pengembangan diri. Piagam dapat dimiliki hanya dengan membayar biaya pendaftaran tanpa mengikuti kegiatan.

Kesulitan penyusunan semakin tinggi bila dokumen-dokumen yang terkait dengan persuratan sekolah yang diperlukan tidak dimiliki oleh guru dan arsipnya juga tidak disimpan oleh sekolah. Hal ini terkait dengan sistem pengarsipan yang ada di sekolah, terutama menyangkut kinerja kepala sekolah sebagai administrator. Rata-rata SD di Kota Semarang tidak memi- 
liki tenaga administrasi khusus, sehingga banyak tugas administrasi ditangani oleh kepala sekolah.

Berdasarkan hasil penelitian, dokumen asli yang sulit diperoleh adalah dokumen yang berhubungan dengan komponen pendidikan dan latihan yang menyangkut bukti fisik berupa sertifikat, prestasi akademik yang berkaitan dengan pembimbingan siswa terkait surat tugas dan fotocopy piagam siswa, pengalaman organisasi di bidang kependidikan dan sosial, dan penghargaan yang relevan dengan bidang pendidikan, serta dokumen keterangan atau penghargaan yang berhubungan dengan penugasan di daerah terpencil. Meski demikian, komponen-komponen itu memungkinkan untuk dibuat ulang sesuai dengan kebutuhan.

Temuan penelitian menunjukkan bahwa banyak bukti fisik asli yang dilampirkan merupakan bukti fisik yang dibuat ulang oleh kepala sekolah, meskipun tetap mengacu pada agenda surat keluar dari sekolah. Solusi lain adalah meminjam arsip sekolah yang berkaitan dengan surat tugas dan piagam siswa untuk dokumentasi, bahkan meminjam piagam pada siswa yang telah lulus. Pembuatan surat tugas oleh kepala sekolah untuk guru dalam kegiatan ekstrakurikuler atau pembimbingan siswa tidak dibuat berdasarkan kompetensi. Pertimbangan kemanusiaan masih ditemui di lapangan. Sebagai contoh, seorang guru yang tidak kompeten di bidang kepramukaan bisa dimasukkan dalam tim pembimbing lomba pramuka.

Langkah akhir dari penyusunan dokumen portofolio adalah verifikasi dokumen oleh kepala sekolah. Verifikasi dokumen yang dilakukan oleh kepala sekolah menyangkut dua hal yaitu: (1) melakukan penilaian pada komponen perencanaan dan pelaksanaan pembelajaran serta penilaian dari atasan, dan (2) mengecek keaslian dan keabsahan keseluruhan dokumen. Penilaian perencanaan dan pelaksanaan pembelajaran seharusnya dilakukan dengan melakukan observasi langsung terhadap proses pembelajaran di kelas dan menilai rencana program pengajaran yang telah disiapkan guru. Hasil penelitian menunjukkan bahwa kepala sekolah sebagian melaksanakan penilaian dengan supervisi langsung tetapi ada kepala sekolah yang menilai dengan menggunakan hasil supervisi sebelumnya. Penilaian dari atasan tentang kinerja guru lebih menekankan pada kompetensi kepribadi- 
an dan sosial. Hal ini pun dilaksanakan berdasarkan data-data penilaian guru yang telah ada.

Verifikasi kedua yang dilaksanakan oleh kepala sekolah adalah mengecek keaslian dan keabsahan keseluruhan dokumen portofolio. Hasil penelitian menunjukkan bahwa semua kepala sekolah melakukan pengesahan dokumen portofolio dengan membubuhkan tanda tangan pada dokumen tersebut. Belum pernah melakukan pembatalan karena ditemukan dokumen yang tidak absah. Hal ini dilakukan karena rasa kasihan dan memberikan penghargaan pada guru yang telah menjadi peserta disebabkan oleh pengabdian yang bersangkutan sebagai guru sudah relatif lama.

Hasil penelitian terkait pengorganisasian sertifikasi jalur portofolio menunjukkan bahwa pengorganisasian tidak berjalan dengan baik. Hal ini dapat diidentifikasi dengan tidak maksimalnya kinerja masing-masing bagian dalam melaksanakan tugas dan fungsinya masing-masing ketika penyusunan portofolio. Guru sebagai peserta sertifikasi tidak semuanya memahami tugas dan fungsinya sebagai guru dan kepala sekolah kurang menjalankan fungsi manajer dan supervisor secara maksimal.

\section{Pelaksanaan}

Pelaksanaan sertifikasi jalur portofolio terkait dengan aspek pengumuman hasil, penyerahan sertifikat, dan pencairan tunjangan. Pengumuman hasil penilaian portofolio dilakukan oleh LPMP yang dapat diakses di internet dengan ditembuskan kepada Dinas Pendidikan.

Hasil penelitian menunjukkan bahwa masih banyak responden yang tidak mengetahui kejelasan informasi tentang pengumuman hasil penilaian. Hari dan tanggal pengumuman tidak diberitahukan secara jelas oleh LPMP atau Dinas Pendidikan ketika peserta sudah selesai menyerahkan portofolio. Peserta yang aktif mencari dan mempunyai koneksi mendapatkan informasi yang lebih cepat daripada Dinas Pendidikan. Skor hasil penilaian portfolio dapat diketahui oleh peserta secara transparan, namun masih ada responden yang sampai saat ini tidak mengetahui skor yang diperoleh. Pengumuman yang ditempel di Dinas Pendidikan adalah pengumuman bagi peserta yang tidak lulus dan direkomendasikan untuk mengikuti 
PLPG. Hal ini menunjukkan bahwa antara Dinas Pendidikan, LPMP, dan LPTK tidak ada koordinasi yang maksimal untuk mempublikasikan hasil penilaian pada peserta.

Peserta yang dinyatakan lolos berhak menerima sertifikat pendidik dari LPTK penyelenggara. Hasil penelitian menunjukkan bahwa penyerahan sertifikat pendidik dilakukan secara langsung bagi peserta yang lulus portofolio oleh LPTK. Peserta yang lulus melalui PLPG diberikan setelah proses pelatihan selesai.

Pada tahun 2007 dan 2008, penyerahan secara langsung dengan menggunakan model wisuda dengan biaya rata-rata Rp 75.000 per orang. Biaya tersebut digunakan untuk biaya konsumsi dan penyelenggaraan. Penyerahan dengan menggunakan prosesi wisuda tidak berjalan baik. Sertifikat pendidik hanya diserahkan secara simbolik. Setelah wisuda selesai, peserta mengambil sertifikatnya di ruang tertentu tanpa dibagi jenjang dan wilayah kerjanya. Peserta yang berjumlah ribuan menciptakan antrian yang lama, panjang, dan tidak tertib. Pada tahun 2009, penyerahan sertifikat pendidik dilakukan di Dinas Pendidikan secara terpusat dan tanpa ditarik biaya. Antrian yang panjang dan tidak tertib terjadi lagi pada model penyerahan yang kedua tersebut. Akhirnya, pada tahun 2010 penyerahan sertifikat dilakukan di UPTD kecamatan. Kepala UPTD atau yang mewakili menyerahkan langsung kepada guru yang bersangkutan atau kepada kepala sekolah kemudian diteruskan kepada guru-gurunya yang lolos sertifikasi.

Pencairan tunjangan profesi didahului dengan pemberkasan untuk mendapat Surat Keputusan Penerimaan Tunjangan Profesi (SKPTP) yang terbit setiap satu tahun anggaran. Pencairan tunjangan dilakukan dengan mengumpulkan berkas Surat Pernyataan Menjalankan Tugas (SMPT) dan Surat Keterangan Masih Aktif Mengajar yang ditandatangani kepala sekolah, fotokopi SK pembagian tugas mengajar, fotokopi jadwal pelajaran, dan fotokopi buku rekening. Besarnya tunjangan profesi sesuai yang tertulis dalam SK Tunjangan yaitu sama dengan gaji pokok untuk guru PNS dan Rp 1.500.000,00 untuk guru Non-PNS, kecuali guru Non-PNS yang memiliki SK Impassing. Guru yang tidak memenuhi syarat ditunda pencairan tunjangan profesinya. Pencairan pada tahap pertama adalah dibayarkan un- 
tuk tiga bulan pertama pada bulan ketiga. Pembayaran selanjutnya dilakukan setiap bulan pada satu tahun anggaran.

Hasil penelitian di lapangan menunjukkan bahwa pencairan tunjangan disampaikan oleh beberapa responden mengalami keterlambatan, namun di akhir tahun anggaran dicairkan secara keseluruhan. Masih ada responden yang menerima tunjangan 10 bulan, dan yang 2 bulan belum dibayarkan sampai tahun anggaran berakhir. Menurut informasi dari Dinas Pendidikan, kekurangan 2 bulan tersebut akan dibayarkan pada tahun anggaran 2011, namun sampai bulan April 2011 tetap belum dibayarkan. Hasil penelitian juga mencatat ada peserta kuota tahun 2010 yang belum menerima tunjangan profesi sampai bulan April 2011.

Kendala lain pencairan tunjangan profesi untuk guru Non-PNS adalah ketidaksesuaian antara gaji yang tertulis di SK Tunjangan dan SK Inpassing. Jalur pencairan tunjangan profesi juga tidak sama antara guru PNS dengan guru Non-PNS. Guru PNS lewat kas daerah kota/kabupaten, sementara untuk guru Non-PNS berasal dari dana konsentrasi yang diterimakan lewat Dinas Pendidikan Provinsi. Pencairan lewat tunjangan bagi guru PNS melalui kas daerah dinilai lebih lancar dan lebih cepat.

Hasil penelitian terkait pelaksanaan sertifikasi guru jalur portofolio menunjukkan bahwa pengumuman hasil, penyerahan sertifikat pendidik, dan penyaluran tunjangan sebagai aspek pelaksanaan, tidak berjalan dengan maksimal. Hal ini disebabkan karena kurangnya kesamaan pemahaman dari guru, kepala sekolah, Dinas Pendidikan, LPMP, dan LPTK terhadap pola pelaksanaan sertifikasi, di samping lemahnya sistem koordinasi berbagai pihak.

\section{Pengawasan}

Pengawasan terhadap guru tersertifikasi dilakukan oleh kepala sekolah sebagai atasan langsung atas nama Dinas Pendidikan. Pengawasan kepala sekolah lebih dititikberatkan pada supervisi pelaksanaan pembelajaran sesuai tugas dan fungsi kepala sekolah sebagai supervisor. Hasil pengawasan kepala sekolah dapat digunakan sebagai acuan untuk pencairan 
tunjangan profesi, di samping sebagai kontrol terhadap peningkatan kualitas pembelajaran di kelas.

Hasil penelitian menunjukkan bahwa kepala sekolah yang menggunakan kewenangan dengan maksimal menyebabkan guru-guru dapat termotivasi melaksanakan tugas dengan maksimal. Kepala sekolah yang mampu melaksanakan supervisi dan memberikan target pencapaian KKM yang harus meningkat pada guru tersertifikasi, menjadikan guru tersebut merasa terpacu untuk meningkatkan nilai KKM di kelasnya. Kepala sekolah yang hanya menghimbau dan memotivasi tanpa memberikan target pada guru, menyebabkan kinerja guru belum maksimal.

Hasil penelitian juga menunjukkan bahwa guru secara pribadi memiliki tanggung jawab moral untuk meningkatkan diri. Guru yang seperti itu akan menerapkan tanggung jawabnya dalam proses pembelajaran. Guru akan selalu melakukan inovasi-inovasi dalam. Selain itu, guru juga meningkatkan diri melalui studi lanjut, memperkaya referensi, dan mengikuti forum-forum ilmiah. Bahkan, ada beberapa guru tersertifikasi yang telah menjadi tutor dan fasilitator bagi sesama guru meski masih dalam lingkup KKG.

Sebagian guru yang belum termotivasi secara maksimal untuk meningkatkan diri terutama dalam proses pembelajaran, kepala sekolah berwenang memberikan punishment. Punishment yang dapat diterapkan misalnya memberi teguran atau tidak memberi tugas jam mengajar sebanyak 24 jam per minggu. Jumlah jam mengajar tersebut adalah salah satu syarat untuk menerima tunjangan profesi. Langkah yang efektif dari kepala sekolah dibutuhkan untuk mengelola kinerja guru tersertifikasi agar berjalan optimal.

Kepala sekolah yang mendapat sertifikat profesi wajib mengajar minimal 6 jam pelajaran per minggu. Kepala sekolah harus melaksanakan pembelajaran dengan baik, sebagaimana guru tersertifikasi lainnya. Supervisi dari pengawas diperlukan untuk mengontrol pelaksanaan tugas mengajar oleh kepala sekolah.

Hasil penelitian terkait pengawasan sertifikasi jalur portofolio terutama pengawasan yang dilakukan oleh kepala sekolah dan pengawas belum 
berjalan maksimal dan belum bisa dijadikan acuan sebagai peningkatan profesi guru. Hal ini disebabkan karena kepala sekolah dan pengawas tidak melaksanakan fungsi pengawasan secara maksimal terutama pengawasan terhadap guru dan kepala sekolah dalam merencanakan dan melaksanakan proses pembelajaran di kelas, sebagai tolok ukur peningkatan profesi.

\section{Simpulan}

Berdasarkan hasil penelitian yang telah dilakukan tentang manajemen sertifikasi guru jalur portofolio bagi guru Sekolah Dasar di Kota Semarang dapat ditarik kesimpulan sebagai berikut.

1. Perencanaan sertifikasi jalur portofolio tidak berjalan dengan baik, dari aspek sosialisasi prosedur tidak tuntas dan data tidak valid.

2. Pengorganisasian sertifikasi jalur portofolio tidak berjalan dengan baik, dari aspek penyusunan dan verifikasi dokumen portofolio tidak sesuai dengan buku panduan.

3. Pelaksanaan sertifikasi guru jalur portofolio tidak berjalan dengan baik, dari pengumuman hasil, penerimaan sertifikat, dan pencairan tunjangan yang tidak sesuai dengan prosedur.

4. Pengawasan sertifikasi jalur portofolio tidak berjalan dengan baik karena logika berpikir pelaksana yang kurang tepat.

Upaya perbaikan manajemen dalam penyelenggaraan sertifikasi guru harus terus diupayakan. Masukan bagi pihak yang berwenang dan bersangkutan dengan penyelenggaraan sertifikasi guru adalah sebagai berikut.

1. Untuk memaksimalkan perencanaan sertifikasi guru jalur portofolio perlu disiapkan database guru yang memadai dan proses sosialisasi perlu dilaksanakan sesuai dengan tujuan yang diharapkan.

2. Untuk memaksimalkan pengorganisaian sertifikasi jalur portofolio perlu dilaksanakan pembagian tugas dan wewenang yang jelas antara Dinas Pendidikan sebagai pelaksana di tingkat kota dan kepala sekolah sebagai pelaksana di tingkat sekolah, serta memaksimalkan koordinasi antara keduanya. 
3. Untuk memaksimalkan pelaksanaan sertifikasi jalur portofolio perlu dibentuk tim khusus untuk memantau penyusunan dokumen portofolio dan perlu adanya verifikasi ulang oleh Dinas Pendidikan terhadap portofolio peserta sebelum dilakukan penilaian.

4. Untuk memaksimalkan pengawasan sertifikasi jalur portofolio oleh kepala sekolah terhadap guru-guru yang telah bersertifikat perlu dibuatkan panduan khusus tentang pola pengawasan dan supervisi yang dilakukan oleh kepala sekolah.

\section{Daftar Pustaka}

Depdiknas. (2005). Undang-Undang RI Nomor 14 Tabun 2005, tentang Guru dan Dosen. . (2005). Peraturan Menteri Pendidikan Nasional RI Nomor 19 Tabun 2005, tentang Standar Nasional Pendidikan.

. (2007). Peraturan Menteri Pendidikan Nasional RI Nomor 14 Tabun 2007, tentang Standar Proses. . (2009). Peraturan Menteri Pendidikan Nasional RI Nomor 10 Tabun 2009, tentang Sertifikasi Guru dalam Jabatan.

Farisi, Muhammad Iman. (2007). Refleksi professional: sertifikasi pendidik dan standarisasi profesionalitas guru. Artikel majalah Pamerte, dari http://utsurabaya.files.wordpress.com. Diambil tanggal 27 April 2011.

Kemendiknas. (2010). Buku 1 pedoman penentuan peserta sertifikasi guru dalam jabatan. Direktorat Jenderal Profesi Pendidik Dirjen PMPTK Kemendiknas.

- (2009). Buku 3 pedoman penyusunan portofolio sertifikasi guru dalam jabatan. Direktorat Jenderal Profesi Pendidik Dirjen PMPTK Kemendiknas. 
. (2009). Buku 2 Petunjuk Teknis Pelaksanaan Sertifikasi Guru dalam Jabatan. Direktorat Jenderal Pendidikan Tinggi Kemendiknas. - (2010). Pedoman pelaksanaan penyaluran tunjangan profesi melalui dana dekonsentrasi. direktorat Jenderal Profesi Pendidik Dirjen PMPTK Kemendiknas.

Miles, Matthew B. \& Huberman, A. Michael. (1994). Qualitative data analysis. New York: Sage Publications.

Moleong, Lexy J. (1998). Metodologi penelitian kualitatif. Bandung: PT Remaja Rosda Karya.

Rusman. (2008). Manajemen kurikulum. Bandung: Sekolah Pascasarjana UPI. 